\title{
Orlo H. Clark Festschrift
}

April 4, 2008

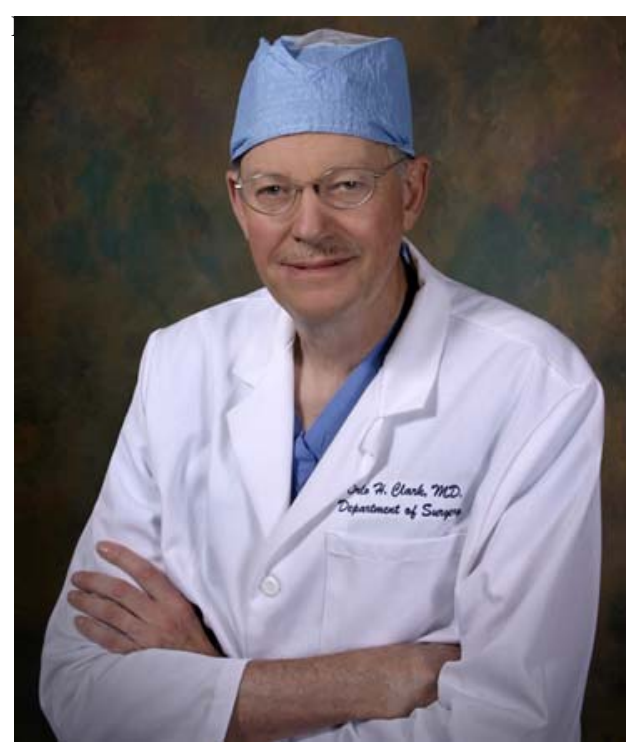

(C) Société Internationale de Chirurgie 2009 